Arq. Bras. Med. Vet. Zootec., v.73, n.1, p.162-168, 2021

\title{
The longevity of Aedes aegypti mosquitoes is determined by carbohydrate intake
}

[A longevidade de mosquitos Aedes aegypti é determinada pela ingestão de carboidrato]

$$
\text { A.P.V. Posidonio }{ }^{1} \text {, L.H.G. Oliveira }{ }^{2} \text {, H.L. Rique }{ }^{1} \text {, F.C. Nunes }{ }^{3 *}
$$

${ }^{1}$ Aluno de graduação - Centro de Biotecnologia, Universidade Federal da Paraíba.

${ }^{2}$ Aluna de pós-graduação - Centro de Biotecnologia, Universidade Federal da Paraíba.

${ }^{3}$ Centro de Biotecnologia, Universidade Federal da Paraíba.

\begin{abstract}
Aedes aegypti is the vector of several viral diseases. The main way to control these diseases is to fight the vector. Thus, it is necessary to breed mosquitoes in the laboratory in order to develop strategies to control these insects. In laboratories, different carbohydrates are used for feeding mosquitoes. The aim of this study is to evaluate the longevity and the weight of Ae. aegypti fed with different carbohydrates diets. As methods, 120 mosquitoes were distributed in insectaries and each group received a different diet, based on honey, dextrose or maltodextrin. To assess the longevity, survival analysis was performed using the Long Rank test and chi square test. To assess the weight, the dead insects were frozen and weighed at the end of the experiment. As results it was observed that mosquitoes fed with the honey, maltodextrin and dextrose diet lived on average 33, 35 and 47 days respectively. When weight was assessed, mosquitoes fed with honey weighed $125 \pm(35.3) \mu \mathrm{g}$, while those fed with dextrose and maltodextrin weighed $225 \pm(35.3) \mu \mathrm{g}$ and 275 $\pm(35.3) \mu \mathrm{g}$ respectively. The results show that the intake of dextrose and maltodextrin by Ae. aegypti adults increases their survival and their weight.
\end{abstract}

Keywords: honey, dextrose, maltodextrin, adult diet

\section{RESUMO}

$O$ Aedes aegypti é vetor de várias doenças virais. A principal maneira de controlar essas doenças é combatendo o seu vetor. Nesse sentido, é necessário criar esses mosquitos em laboratório, visando desenvolver estratégias de controle. Nos laboratórios, diferentes carboidratos são utilizados na alimentação de mosquitos. O objetivo deste estudo é avaliar longevidade e peso de Ae. aegypti alimentados com diferentes fontes de carboidratos. Como método, distribuíram-se 120 mosquitos insetários. Cada grupo recebeu uma dieta diferente à base de mel, dextrose ou maltodextrina. Para avaliar a longevidade, a análise de sobrevida foi realizada pelo teste de Logrank e pelo teste de qui quadrado. Para avaliar o peso, os insetos mortos foram congelados e pesados no final do experimento. Como resultado, observouse que os mosquitos alimentados com a dieta à base de mel, maltodextrina e dextrose viveram em média 33, 35 e 47 dias, respectivamente. Com relação ao peso, os mosquitos alimentados com mel pesavam 125 $\pm(35,3) \mu \mathrm{g}$, enquanto os alimentados com dextrose e maltodextrina pesavam $225 \pm(35,3) \mu g$ e $275 \pm$ $(35,3) \mu g$, respectivamente. Os resultados mostram que a ingestão de dieta à base de dextrose e maltodextrina por Ae. aegypti adultos aumenta sua sobrevivência e seu peso.

Palavras-chave: mel, dextrose, maltodextrina e dieta para adultos

\section{INTRODUCTION}

Aedes (Stegomyia) aegypti (L.) is the vector of several arboviruses of importance in public health, such as dengue, zika and yellow fever ( $\mathrm{Li}$ et al., 2017). The Ae. aegypti is currently spread on all continents in the world, including North America and Europe, with the potential to spread disease among people and animals. Today, about half of the world population is at risk of acquiring

Recebido em 16 de junho de 2020

Aceito em 8 de setembro de 2020

*Autor para correspondência (corresponding author)

E-mail: fabiola@cbiotec.ufpb.br 
dengue, for example (Kraemer et al., 2015). The most common way to control arboviruses transmitted by Ae. aegypti is through combating the vector, especially with insecticides (Nunes et $a l ., 2015)$. To make these researches feasible it is necessary to raise and maintain mosquitoes in laboratories.

The diet of mosquitoes raised in the laboratory is a key point for the proper development of the insect colony. Maintaining sources of carbohydrates, proteins, lipids and essential amino acids is essential to ensure their longevity and proper reproduction (Marques et al., 2018). There are many studies that show the importance of adequate feeding of mosquito larvae and their correlation with their reproduction and even with the pathogen-vector interaction (Caragata et al., 2016; Linenberg et al., 2016; Somda et al., 2017). In the wild, adult mosquitoes generally feed on plant sap, but the females also need blood feeding for egg production and development (Godoy et al., 2015; Marques et al., 2018).

To get an idea of how much mosquito nutrition is something to consider, studies show that it can influence both insect mortality and its interaction with pathogens. Low food intake, in addition to increasing mosquito mortality, can delay the development of pathogens such as Plasmodium falciparum in Anopheles stenphensi (Shapiro et al., 2016). Aedes aegypti is considered a great model for scientific studies, as it has high hatching rates and adapts to different diets when compared to Anopheles gambie (Benedict et al., 2020). Even considering this potential for adaptation, it is important to understand the influence of certain diets on the development of these mosquitoes.

Since in nature, the main carbohydrate source of mosquitoes comes from plants, it is important to note that the sugar synthesized through photosynthesis is distributed throughout the body of the plant, mainly in the form of sucrose (Paulsen et al., 2019). It is interesting to note that the sap of some plants, such as Agave sisalana can cause lethal damage to the cells of the digestive system of Ae. aegypti (Nunes et al., 2015).

In research laboratories adult mosquitoes are usually fed with a sugar solution with variable concentrations. In this sense, there are few studies about the influence of the sugary diet on the development of mosquitoes. Thus, the aim of this study was to evaluate the effects of 3 different diets composed of honey, dextrose or maltodextrin, evaluating aspects such as longevity and weight, contributing to define the best type of diet for its maintenance in the laboratory environment.

\section{MATERIAL AND METHODS}

Aedes aegypti of Rockefeller João Pessoa strain were obtained from the Laboratory of Biotechnology Applied to Parasites and Vectors in the Biotechnology Center, at Federal University of Paraíba. The insects are maintained in a Biological Oxygen Demand (BOD) incubator, under controlled conditions of temperature $27^{\circ} \mathrm{C} \pm 2{ }^{\circ} \mathrm{C}$, relative air humidity $75 \% \pm 5 \%$ and light and dark 12-hour photoperiod. For the preparation of liquid diets, organic honey from Apisvida ${ }^{\circledR}$, Dextrose from Max Titanium ${ }^{\circledR}$ and Maltodextrin from Neonutri® were used.

Three different diets were evaluated: diet 1- $10 \%$ solution of honey in distilled water $(0.085 \mathrm{~g} / \mathrm{mL}$ of carbohydrate), diet 2 - solution of $10 \%$ dextrose in distilled water $(0.092 \mathrm{~g} / \mathrm{mL}$ of carbohydrate), diet $3-10 \%$ maltodextrin solution in distilled water $(0.093 \mathrm{~g} / \mathrm{mL}$ carbohydrate). The diets were prepared weekly and stored in the refrigerator. The amount of carbohydrates and calories for each diet are shown in Table 1.

Table 1. Nutritional information of the diets

\begin{tabular}{lcc}
\multicolumn{1}{c}{ Diet } & Calories/g & Carbohydrates $/ g$ \\
\hline Honey & 3.5 & 0.85 \\
Dextrose & 3.7 & 0.92 \\
Maltodextrin & 3.7 & 0.93
\end{tabular}

Two hundred eggs were placed in plastic trays containing distilled water for hatching. After hatching, the larvae were fed with dog food and distributed to 6 insectaries, 2 for each type of feed (replicate). In this early larval phase, sexing is not possible, and it was assumed that their random choice would result in a representative distribution of each sex. The longevity assessment started with each insectarium containing 20 adult mosquitoes of the same age, totaling 120 insects. For feeding, a feminine tampon, brand Intimus ${ }^{\circledR}$, was used, which was moistened every 2 days with the diets and fixed to the lid of each insectarium 
by the cord itself. The feeding device was changed weekly until the end of the experiment. The insectaries were kept under controlled conditions of temperature $27^{\circ} \mathrm{C} \pm 2^{\circ} \mathrm{C}$, relative air humidity $75 \% \pm 5 \%$ and light and dark 12-hour photoperiod (Figure 1)
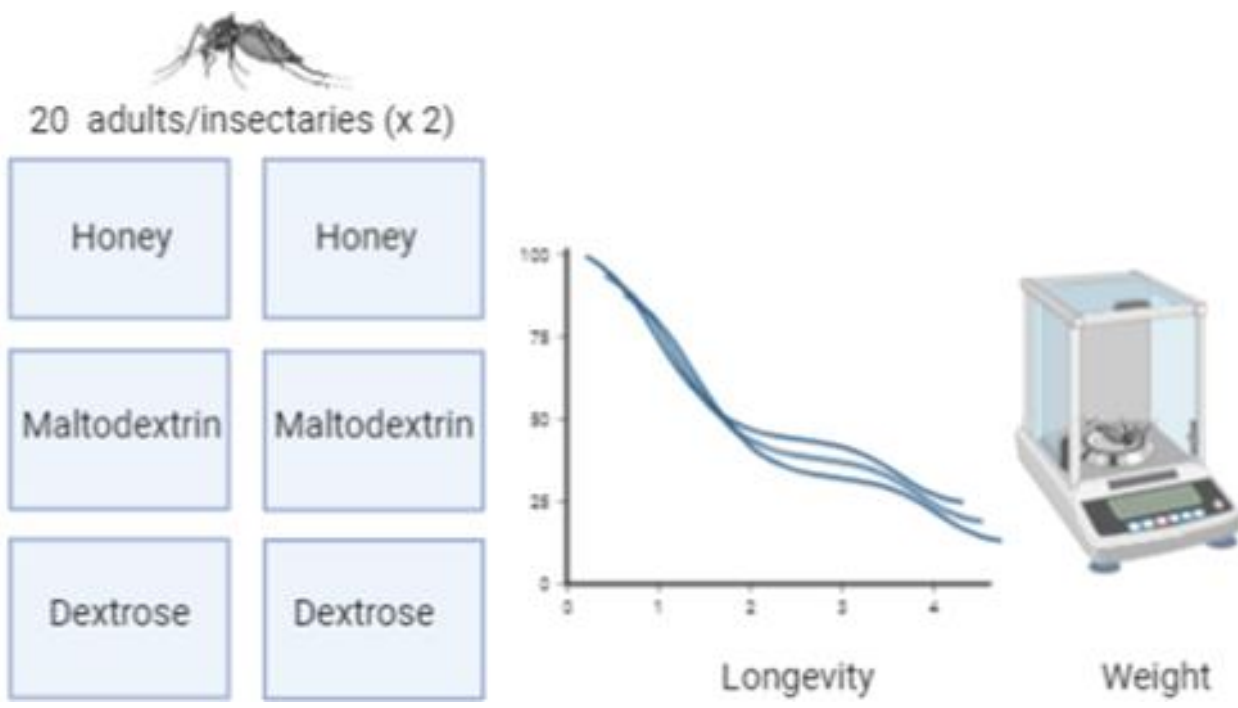

Figure 1. Experimental trial design. For each diet, 40 Ae. aegypti mosquitoes were observed, 20 at each insectary. Mosquitoes were observed until their death, which was recorded daily. When dying, mosquitoes were collected and frozen $\left(-20^{\circ} \mathrm{C}\right)$ until the end of the experiment, when they were weighed.

To assess the longevity of mosquitoes, daily checking and recording of the occurrence of deaths in each insectarium was carried out. After registration, mosquitoes were removed from insectaries. This assessment was carried out until there were no more mosquitoes alive. The analysis of longevity was performed with the graph pad Prism program, using the log-rank test (MantelCox) to evaluate the different survival curves. The $P$ value tests the null hypothesis that the survival curves are identical $(\mathrm{P}<0.05)$.

To assess the weight of mosquitoes in each diet, a precision scale was used. Each insectarium was checked daily for collection of dead mosquitoes. These mosquitoes were collected and stored in plastic tubes identified according to the diet and kept in a freezer at $-20^{\circ} \mathrm{C}$ until all had died. At the end of the longevity experiments, the mosquito pool for each tube was weighed and the average individual weight was calculated. Statistical analysis was performed using ANOVA with Tukey's post-test $(\mathrm{P}<0.05)$, with the graph $\mathrm{Pad}$ Prism version 5.0 program. All procedures were approved by the Federal University of Paraiba Animal Care and Use Committee (Protocol CEUA 029/2017).

\section{RESULTS}

In this study, the survival and weight of mosquitoes fed different carbohydrate sources were evaluated. Mosquitoes fed the honey-based diet lived an average of 33 days, whereas those fed with maltodextrin and dextrose lived 35 and 47 days, respectively. Survival analysis showed that mosquitoes fed with dextrose survived an average of 14 days longer than those fed with the honey solution (33 days vs 47 days), this difference being statistically significant. Assessing longevity, the longest survival time was 64 days, both for the group fed with maltodextrin and for insects fed with dextrose.

In the group fed with honey, mosquitoes lived a maximum of 63 days (Figure 2). Mosquitoes fed with the honey-based diet reached $50 \%$ mortality on day 31, while in the groups fed with maltodextrin and dextrose this percentage was only reached after 35 and 46 days respectively. There was a statistical difference between the survival curves of the group fed with honey compared to that of dextrose. 
When evaluating the different groups week by week, it is possible to observe a trend of greater mortality in mosquitoes fed with honey, when compared to those fed with maltodextrin and dextrose (Figure 3). In weeks 3, 5, 6, 7, 8 and 9, the best performance was observed in the group of mosquitoes fed with dextrose, as there were more live mosquitoes $(5.5 \%, 5.5 \%, 6.5 \%, 6 \%$ and $6 \%$, respectively).

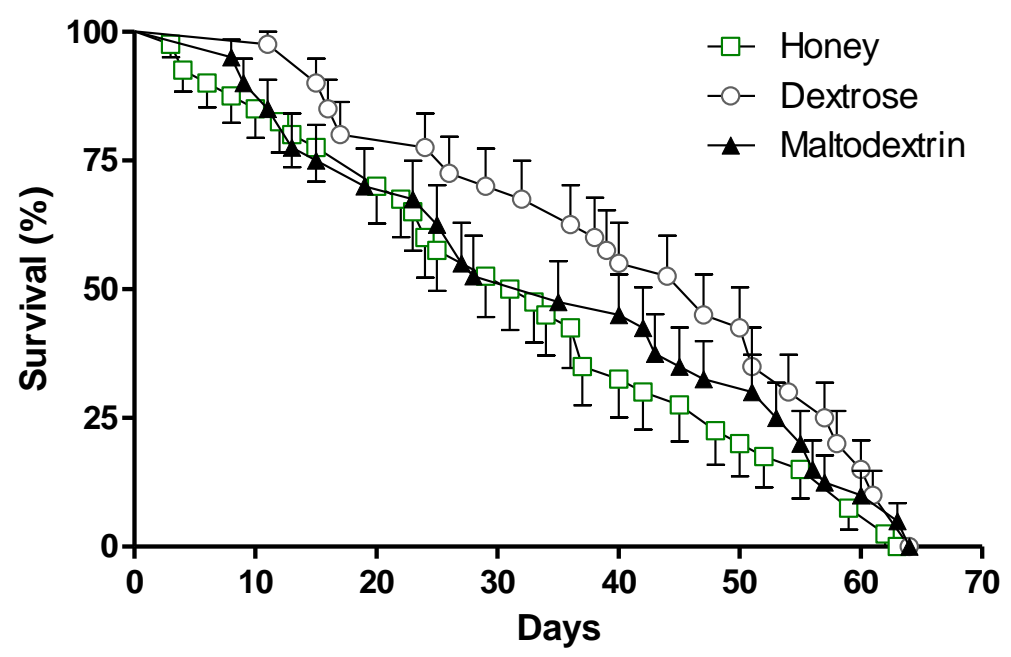

Figure 2. Effect of three different diets on adult Ae. aegypti mosquito's survival. Each line represents 40 mosquitoes per treatment (two replicates for each diet). The error bars represent \pm 1 standard error (SE), and the p-value $<0.05$.

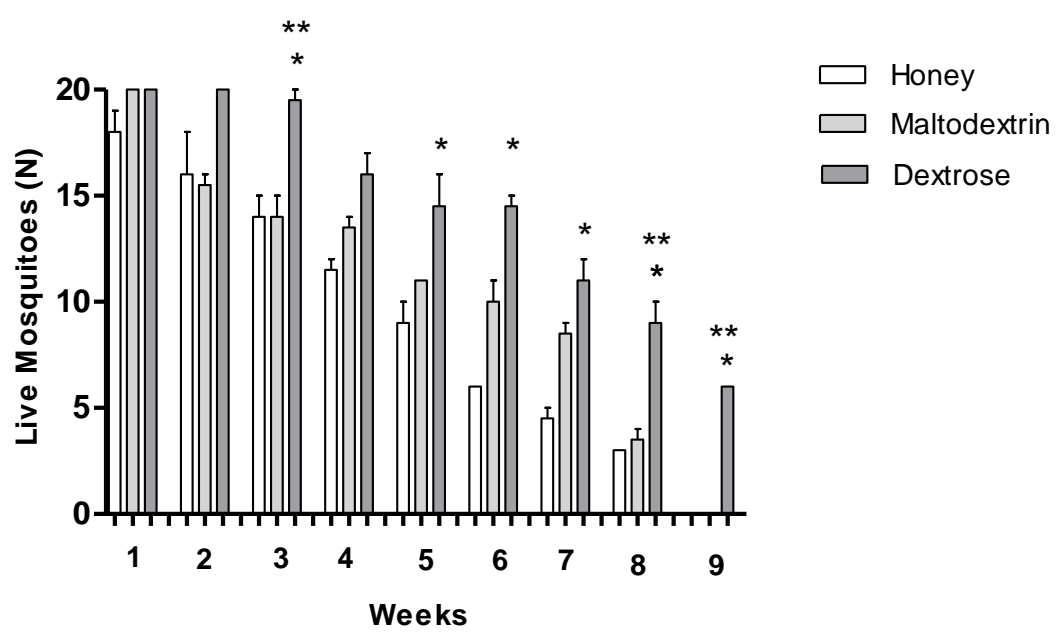

Figure 3. Amount of alive Ae. aegypti mosquitos per week according to the dietary carbohydrate source. * Significant difference between dextrose and honey, and ** between maltodextrin and honey ( $\mathrm{p}$-value $<0.05)$. Error bars represent the standard error.

When the weight of mosquitoes fed with different diets was evaluated, it was observed that mosquitoes fed with honey had an average weight of $125 \pm(35.3) \mu \mathrm{g}$, while those in the dextrose group weighed $225 \pm(35.3) \mu \mathrm{g}$ and those of the the maltodextrin group weighed $275 \pm(35.3) \mu \mathrm{g}$.
The statistical difference was significant for the maltodextrin group when compared to the group fed with honey $(\mathrm{P}<0.05)$. Maltodextrin-fed mosquitoes weighed 2.2 times more than honeyfed mosquitoes (Figure 4). 


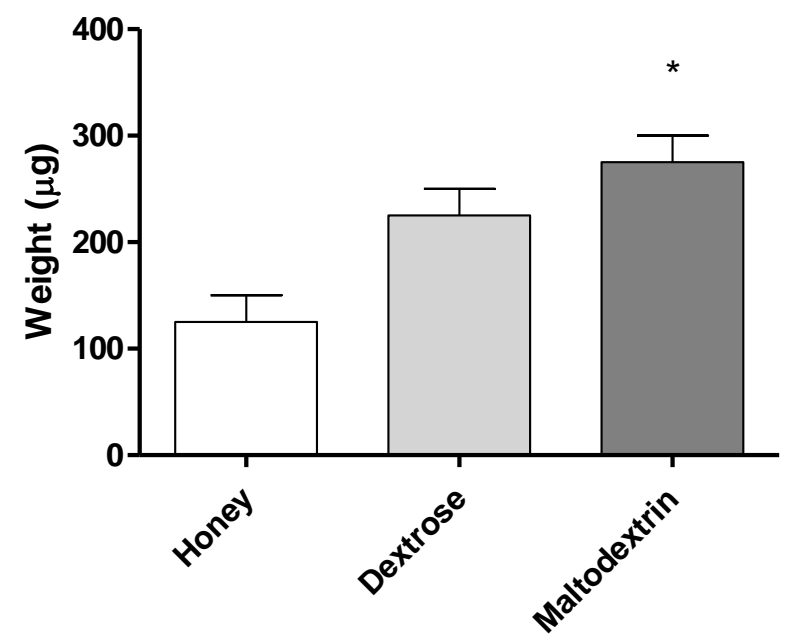

Figure 4. Average weight of Ae. aegypti mosquitos $(\mu \mathrm{g})$ according to the source of carbohydrate intake. * Statistically different with a p-value $<0.05$. Error bars represent the standard error (SE).

\section{DISCUSSION}

Mosquitoes need nucleic acids and nucleotides, vitamins, proteins, fat and sugars to develop properly (Merritt, 1992; Damiens et al., 2012; Marques et al., 2018). Each stage of the insect's life has specific nutritional needs and the scarcity of food in the larval phase can cause higher mortality in adulthood (Shapiro et al., 2016). Vitamins and proteins can significantly influence the reproduction of mosquitoes (Marques et al., 2018; Tavares and Silva, 2018). Sugar improves mosquito growth and its need in the diet varies according to its composition (Merritt, 1992). Many studies use sucrose or honey in adult diets (Robich and Denlinger, 2005; Somda et al., 2017; Sasmita et al., 2019).

In our study, adult mosquitoes lived an average of 33 days when they were fed with honey. Those mosquitoes that received the dextrose diet lived an average of 47 days. Shapiro et al (2016) found that female of Anopheles stephensi mosquitoes fed with larger quantities of fish food in the larval phase lived an average of 22.3 days and 15.9 days when fed with little food in the larval phase. In adulthood, these mosquitoes were fed with $10 \%$ glucose solution. In a similar study by Lang et al. (2018), adult males of Aedes aegypti lived on average more than 30 days. In adulthood, these mosquitoes were fed with a $20 \%$ sucrose solution. Somda et al. (2017), evaluating different diets in the larval phase, found a maximum survival of 34 days in adult males of Anopheles arabiensis. Sasmita et al. (2019) found a relationship between the diet and the water temperature in the larval phase and the longevity of male mosquitoes $\left(28.43 \pm 1.84\right.$ days for those fed at $28^{\circ} \mathrm{C}$ and 32 ${ }^{\circ} \mathrm{C}$ with the IAEA 2 diet).

Caragata et al. (2016) compared the effects of carbohydrate-based diet on Ae. aegypti infected with wolbachia. The authors found that mosquitoes fed with a $10 \%$ sugar diet lived an average of 12.28 days longer than those fed with $1 \%$ sugar diet. In our study, this increase was of 14 days with the dextrose-based diet, since in our study the maximum survival time was 47 days, while the group fed with honey lived 33 days. These findings corroborate those found in our study. Another important aspect highlighted by Caragata et al. (2016) was the increase in the levels of nitric oxide (NO) in mosquitoes fed with diets low in carbohydrates. Oliveira et al. (2016) associated the increase in NO levels with the mortality of Ae. aegypti exposed to Agave sisalana. In fact, when we analyzed the three diets evaluated in our study, the honey-based diet has less carbohydrate $(85 \mathrm{mg} / \mathrm{mL})$ than the dextrosebased diet $(92 \mathrm{mg} / \mathrm{mL})$ and the maltodextin-based $\operatorname{diet}(93 \mathrm{mg} / \mathrm{ml})$.

In our study, mosquitoes fed with the maltodextrin diet weighed more than twice as much as mosquitoes fed with honey (275 Vs. $125 \mu \mathrm{g}$ ). Benedict et al. (2020) when researching the 
effects of diets containing fatty acids did not observe large variations in weight between groups. In the study carried out by Lang et al. (2018), the mosquitoes that received the largest amount of food in the larval phase $(0.3 \mathrm{mg}$ diet $)$, were larger than those that received less food ( $0.1 \mathrm{mg}$ diet) ( $2.45 \mathrm{vs} .2 .21 \mathrm{~mm}$ ). In addition, the larger mosquitoes lived longer. In our study, the mosquitoes that lived the least were those that received the honey-based diet, which also weighed less. When testing 4 different diets on Anopheles arabiensis, Somda et al. (2017) saw that mosquitoes that received Mix 14 (based on tuna, beef liver, chickpea and vitamin mix) had a larger wing size than other groups, in addition to reducing the risk of death by $25 \%$.

According to the results found in the present study, both honey, dextrose and maltodextrin are adequate carbohydrate sources for Ae. aegypti feeding in laboratory colonies. However, dextrose diet was able to significantly increase the longevity of mosquitoes. It is noteworthy that of the three sources of carbohydrates used in this study, dextrose is the simplest sugar. Also known as glucose, it is a monosaccharide that is rapidly enters cells via carrier proteins being used as an energy source (Paulsen et al., 2019). Honey has in its composition sugars such as glucose and fructose, and other substances such as proteins, vitamins, amino acids, enzymes, organic acids, mineral substances, water, pollen, sucrose, maltose, malesitosis and other oligosaccharides, in addition to small concentrations of fungi, algae, yeasts (Gois et al., 2013). Thus, it is possible that these other elements present in honey contribute negatively to the development and longevity of Ae. aegypti.

\section{CONCLUSION}

The present study evaluated the effect of 3 diets with different carbohydrate sources on the longenvity and weight gain of Ae. aegypti adults. Although many studies report that any source of carbohydrate is suitable for the maintenance of Ae. aegypti mosquitoes in laboratory, our results showed that the source of carbohydrate interferes with the mosquito development. The honey-based diet was the one with the worst performance, causing the highest mortality in the first 30 days of adult life, in addition to generating lighter insects. The dextrose diet led to an increase of 14 days of life for mosquitoes, being among the 3 diets evaluated, the best for longevity. However, for the best weight gain, the maltodextrin diet presented the best performance. Thus, we conclude that the carbohydrate source of the Ae. aegypti diet can directly interfere with factors such as mortality, longevity and insect weight. The honey-based diet showed the worst performance in all aspects analyzed in the research and should be replaced whenever possible by maltodextrin or dextrose, allowing for better colony development.

\section{REFERENCES}

BENEDICT, M.Q.; HUNT, C.M.; VELLA, M.G. et al. Pragmatic selection of larval mosquito diets for insectary rearing of Anophelesgambiae and Aedes aegypti. PLoS One., v.3, p.1-15, 2020.

CARAGATA, E.P.; REZENDE, F.O.; SIMÕES,T.C. et al. Diet-induced nutritional stress and pathogen interference in wolbachiainfected Aedes aegypti. PLoS Neglected Trop.Dis., v.11, p.1-26, 2016.

DAMIENS, D.; BENEDICT, M.Q.; WILLE, M. et al. An inexpensive and effective larval diet for anopheles arabiensis (diptera: culicidae): eat like a horse, a bird, or a fish? J. Med. Entomol., v.5, p.1001-1011, 2012.

GODOY, R.S.M.; FERNANDES, K.M.; MARTINS, G.F. Midgut of the nonhematophagous mosquito toxorhynchites theobaldi (diptera, culicidae). Sci. Rep., v.5, p.116. 2015 .

GOIS, G.C., LIMA, C.A.B.; SILVA, L.T. et al. Composição do mel de apis mellifera: requisitos de qualidade. Acta Vet. Bras., v.2, p.137-147, 2013.

KRAEMER, M.U.G.; SINKA, M.E.; DUDA, K.A. et al. Theglobal distribution of the arbovirus vectors Aedes aegypti and Ae. Albopictus. Elife, v.4, p.1-18, 2015.

LANG, B.J.; IDUGBOE, S.; MCMANUS, K. et al. The effect of larval diet on adult survival, swarming activity and copulation success in male Aedes aegypti (Diptera: culicidae)." J. Med. Entomol., v.1, p.29-35, 2018.

LI, C.X.; GUO, X.X.; DENG, Y.Q. et al. Vector competence and transovarial transmission of two Aedes aegypti strains to Zika Virus. Emerg. Microbes Infect., v.4, p.1-7, 2017. 
LINENBERG， I.; CHRISTOPHIDES， G.K.; GENDRIN, M. Larval diet affects mosquito development and permissiveness to plasmodium infection. Sci. Rep., v.6, p.1-10, 2016.

MARQUES, J.; CARDOSO, J.C.R.; FELIX, R.C. et al. Fresh-blood-free diet for rearing malaria mosquito vectors. Sci. Rep., v.1, p.1-9, 2018.

MERRITT, R. Feeding behavior, natural food, and nutritional relationships of larval mosquitos. Ann. Rev. Entomol., v.1, p.349-376, 1992.

NUNES, F.C.; LEITE, J.A.; OLIVEIRA, L.H.G.; SOUSA, P.A.P.S. et al. The larvicidal activity of agave sisalana against L4 Larvae of Aedes aegypti is mediated by internal necrosis and inhibition of nitric oxide production. Parasitol. Res., v.2, p.543-549, 2015.

OLIVEIRA, L.H.G.; SOUSA, P.A.P.S.; HILARIO, F.F. et al. Agave sisalana extract induces cell death in Aedes aegypti hemocytes increasing nitric oxide production. Asian Pac. J. Trop. Biomed., v.5, p.396-399, 2016.

PAULSEN, P.A.; CUSTÓDIO, T.F.; PEDERSEN, B.P. Crystal Structure of the Plant Symporter STP10 illuminates sugar uptake mechanism in monosaccharide transporter superfamily. Nat. Commun., v.1, p.1-8, 2019.
ROBICH, R.M.; DENLINGER, D.L. Diapause in the mosquito culex pipiens evokes a metableolic switch from blood feeding to sugargluttony. Proc. Nat. Acad. Sci. USA, v.44, p.15912-15917, 2005.

SASMITA, H.I.; TU, W.C.; BONG, L.J. et al. Effects of larval diets and temperature regimes on life history traits, energy reserves and temperature tolerance of male Aedes aegypti (Diptera: culicidae): optimizing rearing techniques for the sterile insect programmes. Parasit. Vectors, v.1, p.1-16, 2019.

SHAPIRO, L.L.M.; MURDOCK, C.C.; JACOBS, G.R. et al. Larval food quantity affects the capacity of adult mosquitoes to transmit human malaria. Proc. R. Soc. B Biol. Sci., v.1834, p.1-8, 2016.

SOMDA, N.S.B.; DABIRÉ, K.R.; MAIGA, H. et al. Cost-effective larval diet mixtures for mass rearing of anopheles arabiensis patton (Diptera: Culicidae). Parasit.Vectors, v.1, p.1-12, 2017.

TAVARES, N.C. ; SILVA, A.A. Blood supplementation with vitamins increases the fertility of anopheles darlingi (Diptera: culicidae). Rev. Patol. Trop. / J. Trop. Pathol., v.1, p.46-54, 2018. 